\title{
Teaching ESL in a Multilingual Context: a Case Study of Cameroonian Students at High School Level
}

\author{
Franck Jordan FEZEU MOLAPINGa ${ }^{a}$, Türkay BULUT
}

\begin{abstract}
The merits of cultural and linguistic diversity are often praised across the world. This setting is very present in Africa in general and Cameroon in particular, a country with 285 local languages, two official languages, English and French, and several lingua francas that are experiencing a rapid rise. While the governmental and scientific effort in setting up what we call a triangular language education system (mother tongue + $\mathrm{L} 2+$ $L 3$ ) is to be commended, it is worth looking at their distribution and use in everyday life to see whether they benefit academics and whether the results are in line with the expectations of policymakers. This research looks at the health of the teaching of English as a second language in Cameroon's multilingual education system and tries to identify factors that may constrain its implementation. The questionnaire administered to 53 ESL teachers from a variety of backgrounds allowed us to conclude that learning ESL in Cameroon is easier when one has some mastery of one's L1 (local language). The absence of a single national language is a hindrance to linguistic development in schools, but if standardized, the CPE could be a solution.
\end{abstract}

Keywords: Linguistics, Multilingualism, ESL, Lingua Franca, Local languages, Cameroon

\section{Introduction}

In the aftermath of independence, enormous scars have unfortunately remained on the African continent, namely the colonial currency, religion and even language. This legacy, although forced, has unfortunately not escaped Cameroon, which, according to some researchers, continues to use the colonial language out of political pragmatism and loyalty to the former colonist. Officially, the Cameroonian government will rely on official bilingualism and the promotion of national languages in order to promote social cohesion and to live together due to the country's bi-cultural and multilingual nature (Anglophone and Francophone). This is further confirmed by Chumbow (1990) and Chiatoh (2012). They point out that since reunification in 1961, Cameroon has implemented an exoglossic language policy based on the exclusive use of English and French as the languages of teaching and learning. As stated in the 1961 Constitution, "French and English are the official languages of the Federal Republic of Cameroon..." In the 1996 Constitution, there is a step forward as it goes further by stipulating that "the official languages of the Republic of Cameroon are French and English, both languages being of equal value. The State shall guarantee the promotion of bilingualism in the country and shall endeavor to promote and protect the national languages".

Thus, Cameroon inherited from a dual educational system, namely the Anglo-Saxon system based on the former British colonial power model and the Francophone system based on the French model. Cameroonians in the English-speaking regions, who are numerically in the minority, will be educated according to the Anglo-Saxon system, while the reverse is true for French-speaking Cameroonians, who are numerically in the majority.

\section{About the Article}

Type: Research

Received: 27 September 2021

Accepted: 18 November 2021 Published: 22 December 2021 DOI: $10.31805 /$ acjes.1025430

Corresponding Author:

Türkay BULUT

İstanbul Aydın University

İstanbul/Turkey.

E-mail: turkaybulut@aydin.edu.tr

aFranck Jordan FEZEU MOLAPING

ORCID: https://orcid.org/0000-0002-0888-6745

istanbul Aydın University, Faculty of Education Department of Foreign Languages Education, İstanbul, Turkey.

E-mail: fjordanmolaping@stu.aydin.edu.tr

b Türkan BULUT

ORCID: https://orcid.org/0000-0003-0711-6869

istanbul Aydın University, Faculty of Education Department of Foreign Languages Education. İstanbul, Turkey.

E-mail: turkaybulut@aydin.edu.tr

\section{Suggested APA Citation}

Fezeu Molaping, F. J. \& Bulut, T. (2021). Teaching ESL in a multilingual context: a case study of Cameroonian students at high school level Academy Journal of Educational Sciences, 5(2) 79-. http://dx.doi.org/10.31805/acjes.1025430 
Added to this dual system was the 1996 constitution, which favored the introduction of national languages into the language education system. Therefore, Cameroon inherited what we describe as a triangular language education system (mother tongue + second language + third language).

It is no secret that the official bilingualism so praised by the Cameroonian government has never really been effective due to the fact that the English language is marginalized and under-used. Alongside this triangular system, there are two linguafrancas (pidginand Camfranglais) that continueto make their way into the lives of Cameroonians even though they do not yet have a normalized status. Whether in the media, music, digital communication, courts, trade or advertising, Camfranglais and Pidgin have invaded all domains in Cameroon. It is perhaps a little rarer in the administration and the education system because it is informal, but one only has to look closely to realize that these languages are found even in these spheres. In secondary schools, it is common to follow a discussion in Pidgin or Camfranglais between two colleagues and even worse between two students, and this even in administrative offices. Experts believe that unstructured languages (no spelling, no writing conventions, no grammatical rules, no phonological and phonic studies...) like these can only have a negative impact on those that are already well developed and need to be well assimilated and mastered. The danger is twofold, because if it has an impact on the teacher's productivity, one can only wonder what impact it will have on the learner's input. To raise this issue in this research is not risky because we assume that there is a strong chance that these languages have a large impact on the learning/teaching of English as a second language and that it is imperative that the linguistic organization of the country is rethought so that these languages do not clash but complement each other if not, they may end up opening a boulevard for the degradation and extinction of English itself, which runs counter to the official bilingualism so cherished by the Cameroonian government

\section{Review of Literature}

Blasius \& Pius (2014) have worked on the enhancement of the English language in Cameroon from a mother tongue perspective. In their view, the sustainable and effective study of English in Cameroon can best be achieved through the development and use of Cameroonian languages and methods that are culturally appropriate to the lifestyles and experiences of Cameroonians. Furthermore, they believe that the result will be better if pupils at the elementary level of (pre-) nursery education are allowed to study in their mother tongue and in ways that are familiar to them.

Blasius and Lando (2017) have investigated English in Cameroon and focus on issues of teacher language proficiency. The need for such an investigation stems from the fact that over the past three decades, the standards of English in Cameroon, as well as the performance of students in English at the General Certificate of Education (GCE) examination, have been in steady decline. Their observation is also shared by Fontem and Oyetade (2005) and Fontem (2012, p. 136), who suggest that teachers are a contributing factor to the decline in English standards and proficiency in Cameroon. They believe that a lot of time is spent on learner outcomes and little on teacher input because if teachers do not use English properly, students will have no choice but to acquire the misuse to which they are exposed.

In 2013, Ekembe investigated the attitudes and pedagogic practices of English as a foreign language at the University of Yaoundé 1. His research aimed at understanding how the attitudes of EFL students at the University of Yaoundé 1is affected by the teaching of English from a process-oriented perspective. Results generally revealed that learners negative attitude towards English was because of teacher practices. In order words, he shows that there exists a mismatch or discord between the skills developed by the teacher and the purpose for language learning.

Echu (2003) has made a relevant analysis of multilingualism in Cameroon. His research first reviews Cameroon's language policy in different periods and political actors since the German colonial period (1884-1916), the French colonial administration (1916-1960) and the British colonial administration (1916-1960), not forgetting the postindependence period (1960). Focusing on the different measures taken by these actors to deal with the country's dense multilingual situation, his article also examines the different proposals for language policy and language planning made by academics and language specialists about Cameroon.

Gonondo and Djiraro (2016) wrote an article aimed at describing and challenging the ineffectiveness of the use of the two official languages in the Cameroonian higher education system. They have shown the great need and importance of promoting the two languages (English and French). Their paper proposes pragmatic remedial strategies and practical solutions to overcome the difficulties of implementing true individual and personal bilingualism in the Cameroonian higher education system.

The aim of this study is to determine whether multilingualism in the Cameroonian education system is an obstacle to the development of ESL. To this end, the following research questions are formulated:

Q1: What are the views of teachers about the official bilingualism in Cameroon?

Q2: Do Cameroon Pidgin English (CPE) and Camfranglais affect the teaching of English as a second language?

\section{Methodology}

\section{Participants}

There were 57 participants randomly selected from the population. The background's information results demonstrate that, with a slight dominance of female (50.9\%) compared to $(49.1 \%)$ of male, was predominantly in the 20-29 and 30-39 age groups. The majority were trained as teachers with a dominance of graduates from Higher Teachers Training Colleges (HTTC) (58.5\%); this was followed by ELT or linguistics bachelor's degree holders (17\%). There were also ELT and linguistics master's degree holders and Ph.Ds. Some (7.5\%) were TEFL, TESOL and DELTA holders. Their teaching experience generally ranges from 5-10 years. Therefore, we can say that the ESL teaching force in Cameroon is essentially young and qualified. Table 1 is a summary of their profiles:

We were also pleasantly surprised to notice that they come from $9 / 10$ regions of Cameroon (only the north was not represented), with exactly 28 local languages reported as their first language. In addition to their local languages and English that is their working language, our informants had knowledge of French, Pidgin, and Camfranglais.

\section{Instrument}

In order to maximize the effectiveness of the research, we opted for both a qualitative and quantitative approach in this research. We, therefore, administered a questionnaire related 
Table 1. Participant's Profile

\begin{tabular}{|c|c|c|c|c|c|c|c|c|c|}
\hline \multicolumn{10}{|c|}{ Gender } \\
\hline \multicolumn{5}{|c|}{ Male } & \multicolumn{5}{|c|}{ Female } \\
\hline \multicolumn{5}{|c|}{$26(49.1 \%)$} & \multicolumn{5}{|c|}{$27(50.9 \%)$} \\
\hline \multicolumn{10}{|c|}{ Age } \\
\hline \multicolumn{2}{|c|}{$20-29$} & \multicolumn{3}{|c|}{$30-39$} & \multicolumn{2}{|c|}{$40-49$} & \multicolumn{3}{|c|}{$50+$} \\
\hline \multicolumn{2}{|c|}{$29(54.7 \%)$} & \multicolumn{3}{|c|}{$23(43.4 \%)$} & \multicolumn{2}{|c|}{$1(1.9 \%)$} & \multicolumn{3}{|c|}{$\mathrm{O}(0 \%)$} \\
\hline \multicolumn{10}{|c|}{ Training and Education } \\
\hline Graduate & n HTTC & \multicolumn{3}{|c|}{ M.A in ELT/Linguistics } & $\begin{array}{l}\text { B.A in ELT/ } \\
\text { Linguistics }\end{array}$ & $\begin{array}{l}\text { Ph.D. in ELT/ } \\
\text { Linguistics }\end{array}$ & DELTA & TESOL & TEFL \\
\hline \multicolumn{2}{|c|}{$31(58.5 \%)$} & & $4(7.5 \%)$ & & $9(17 \%)$ & $4(7.5 \%)$ & $1(1.9 \%)$ & $2(3.8 \%)$ & $2(3.8 \%)$ \\
\hline \multicolumn{10}{|c|}{ Years of Teaching Experience } \\
\hline \multicolumn{2}{|c|}{$<5$} & \multicolumn{3}{|c|}{$5-9$} & \multicolumn{2}{|c|}{$10-20$} & \multicolumn{3}{|c|}{$20^{+}$} \\
\hline \multicolumn{2}{|c|}{$29(54.7 \%)$} & \multicolumn{3}{|c|}{$21(39.6 \%)$} & \multicolumn{2}{|c|}{$3(5.7 \%)$} & \multicolumn{3}{|c|}{$\mathrm{O}(0 \%)$} \\
\hline \multicolumn{10}{|c|}{ Region of Origin } \\
\hline Adamawa & Centre & East & Far-North & Littoral & North-west & South & South-west & West & Null \\
\hline $2(3.8 \%)$ & $9(17 \%)$ & $1(1.9 \%)$ & $2(3.8 \%)$ & $1(1.9 \%)$ & $3(5.7 \%)$ & $3(5.7 \%)$ & $2(3.8 \%)$ & $25(47.2 \%)$ & $4(9.5 \%)$ \\
\hline \multicolumn{10}{|c|}{ English Proficiency } \\
\hline \multicolumn{2}{|c|}{ Poor } & \multicolumn{3}{|c|}{ Average } & \multicolumn{2}{|c|}{ Good } & & Very good & \\
\hline $0(4$ & & & $7(13.2 \%)$ & & & $.7 \%)$ & & $8(15.1 \%)$ & \\
\hline & & & & & ch Proficiency & & & & \\
\hline $\mathrm{Pc}$ & & & Average & & & & & Very good & \\
\hline $\mathrm{O}(\mathrm{C}$ & & & $8(15.1 \%)$ & & & $.7 \%)$ & & $16(30.2 \%)$ & \\
\hline & & & & & Proficiency & & & & \\
\hline $\mathrm{Po}$ & & & Average & & & & & Very good & \\
\hline 183 & & & $22(41.5 \%)$ & & & 3\%) & & $7(13.2 \%)$ & \\
\hline & & & & Cam & glais Proficier & & & & \\
\hline $\mathrm{Po}$ & & & Average & & & & & Very good & \\
\hline 18 & & & $18(34 \%)$ & & & $8 \%)$ & & $6(11.3 \%)$ & \\
\hline
\end{tabular}

to our research to ESL teachers. The questionnaire included nine questions about their personal information such as their gender, age, education background, language, education and qualifications, years of teaching experience, region of origin and language proficiency level of all languages they know. There were also 16 questions and an open-ended question to obtain their views.

\section{Findings and Discussions}

In order to find out the views of our informants regarding the impact of multilingualism as observed in Cameroon on ESL learning/teaching, we asked 16 questions. The results are mostly varied in view of the fact that they themselves are primarily subject to a certain ethnic and linguistic diversity. Table 2 recapitulates the three questions asked to our informants under this section.

It can be seen that $52.8 \%$ of the informants think that having a good command of one's mother tongue is a prerequisite for learning ESL, while $47.2 \%$ think that it is not. When we asked whether teaching local languages in schools had an impact on ESL learning, 62.3\% answered it had no impact compared to $37.7 \%$ who answered it did have a negative impact. In the same vein, when we asked whether the absence of a common national language was a factor that favored clashes and linguistic disorder, 49\% replied that it did indeed favor this phenomenon as opposed to $43.4 \%$ who replied that it did not. $7.6 \%$ were unsure.

These results are in line with Ekembe (2013), who investigated the attitudes and pedagogic practices of English at the university level. His results indicated that the negative attitudes of the teachers towards English affected the attitudes of the students as well. In order words, he shows that there exists a mismatch or discord between the skills developed by the teacher and the purpose for language learning. This may indicate that as a multiethnic group, they do not view the absence of one official language as a handicap in the education system, but they also support translanguaging in the classroom. As for the impact of the pidgin language (CPE) on the acquisition of English, the data was obtained from five questions. With regard to the influence of CPE, the results show that our informants are slightly influenced by CPE at $32.1 \%$, averagely at $13.2 \%$, too much at $3.8 \%$ and not at all at $50.9 \% .18 .9 \%$ of our informants use this lingua franca to better teach English lessons against $81.1 \%$ who do not. In addition, $15.1 \%$ of these ESL teachers observed that their students use this language very rarely in 
Table 2. Recap of the Impact of Local Languages

Does learning English as a second language with a good command of one's native (local) language make it easier to learn it?

\begin{tabular}{|c|c|c|}
\hline Yes & & No \\
\hline $52.8 \%(28)$ & & $47.2 \%(25)$ \\
\hline \multicolumn{3}{|c|}{ Does teaching local languages at the secondary level affect the learning of English as a second language negatively? } \\
\hline I agree & & I don't agree \\
\hline $62.3 \%(33)$ & & $37.7 \%(20)$ \\
\hline \multicolumn{3}{|c|}{ Does the absence of a single national language encourage linguistic disorder between languages? } \\
\hline Yes & No & No idea \\
\hline $49 \%(26)$ & $43.4 \%(23)$ & $7.6 \%(4)$ \\
\hline
\end{tabular}

Table 3. Recap of the impact of CPE

\begin{tabular}{|c|c|c|c|}
\hline \multicolumn{4}{|c|}{ As an ESL teacher, are you influenced by the CPE? } \\
\hline Slightly & Averagely & Too much & Not at all \\
\hline $32.1 \%(17)$ & $13.2 \%(7)$ & $3.8 \%(2)$ & $50.9 \%(27)$ \\
\hline \multicolumn{4}{|c|}{ As an ESL teacher, are you influenced by the CPE? } \\
\hline Slightly & Averagely & Too much & Not at all \\
\hline $32.1 \%(17)$ & $13.2 \%(7)$ & $3.8 \%(2)$ & $50.9 \%(27)$ \\
\hline \multicolumn{4}{|c|}{ Do you use this pidgin in your classes? } \\
\hline \multicolumn{2}{|c|}{ Yes } & \multicolumn{2}{|c|}{ No } \\
\hline \multicolumn{2}{|c|}{$18.9 \%(10)$} & \multicolumn{2}{|c|}{$81.1 \%(43)$} \\
\hline \multicolumn{4}{|c|}{ Do your students use CPE in the classroom? } \\
\hline Very rarely & Rarely & Quite frequently & Not at all \\
\hline $15.1 \%(8)$ & $35.8 \%(19)$ & $39.6 \%(21)$ & $9.4 \%(5)$ \\
\hline \multicolumn{4}{|c|}{ Do you think that this lingua franca impinges on the good teaching quality of ESL? } \\
\hline \multicolumn{2}{|c|}{ Yes } & \multicolumn{2}{|c|}{ No } \\
\hline \multicolumn{2}{|c|}{$83 \%(44)$} & \multicolumn{2}{|c|}{$17 \%(9)$} \\
\hline \multicolumn{4}{|c|}{ Should CPE be standardized to serve as a national language like Wolof in Senegal and Tswana in Botswana? } \\
\hline \multicolumn{2}{|c|}{ Yes } & \multicolumn{2}{|c|}{ No } \\
\hline \multicolumn{2}{|c|}{$58.5 \%(31)$} & \multicolumn{2}{|c|}{$41.5 \%(22)$} \\
\hline
\end{tabular}

class, $38.5 \%$ stated that they rarely use it, $39.6 \%$ that they use it quite frequently and $9.4 \%$ that they do not use it at all. The majority (83\%) say that this language impinges on the good learning/teaching quality of ESL against (17\%) who says it does not. Finally, $58.5 \%$ of them think that this language should be standardized against $41.5 \%$ who reject this idea. As things stand, we can no longer deny the existence and influence of CPE on ESL teachers and students. The majority is in favor of its standardization, and the majority of students are already using it in school situations.

As with the influence of CPE on ESL teaching and learning, the same questions were asked of our informants with regard to Camfranglais, and this is what came of it. Concerning the impact or influence of Camfranglais, statistics reveal that our informants) are slightly influenced by Camfrangalis at $30.2 \%$, averagely at $13.2 \%$, too much at $1.9 \%$ and not at all at $54.7 \%$. $20.8 \%$ of our informants (ESL teachers) use this lingua franca to facilitate the running of their lessons against $79.2 \%$ who do not. More so, $28.3 \%$ of these ESL teachers observed that their students use this language very rarely in class, $15.1 \%$ stated that they rarely use it, $43.4 \%$ that they use it quite frequently and $13.2 \%$ that they do not use it at all. The majority $(71.7 \%)$ say that this language impinges on the good learning/teaching them suggest that this language should be standardized against $69.9 \%$ who reject this idea.

As with CPE, we also cannot deny the existence and influence of Camfranglais on ESL teachers and students. The only difference is that the majority is against its standardization as they consider it a street language even though the majority of students use it in school situations.

This is not the case, however, in the study by Eloundou (2021), who has worked on the national languages of Cameroon and Camfranglais at the heart of glottophobic and glottophilic representations and who sees Camfranglais as a language which, unlike the national languages, could reduce discrimination and identity closure, perhaps could be an excellent national language.

French is the other official language in Cameroon. To investigate the ESL teachers' perceptions of the impact of French on English Language teaching, we added three questions in the questionnaire. Table 5 illustrates the answers to three questions for their views about French.

It appears that $47.2 \%$ use it very rarely to teach English better to their students; $24.5 \%$ say they use it rarely; $47.2 \%$ very frequently, and just $7.5 \%$ say they do not use it at all. 
Table 4. Recap of the impact of Camfranglais

\begin{tabular}{|c|c|c|c|}
\hline \multicolumn{4}{|c|}{ As an ESL teacher, are you influenced by the Camfranglais } \\
\hline Slightly & Averagely & Too much & Not at all \\
\hline $30.2 \%(16)$ & $13.2 \%(7)$ & $1.9 \%(1)$ & $54.7 \%(29)$ \\
\hline \multicolumn{4}{|c|}{ Do you use this lingua franca to facilitate the running of your lessons? } \\
\hline \multicolumn{2}{|c|}{ Yes } & \multicolumn{2}{|c|}{ No } \\
\hline \multicolumn{2}{|c|}{$20.8 \%(11)$} & \multicolumn{2}{|c|}{$79.2 \%(42)$} \\
\hline \multicolumn{4}{|c|}{ Do your students make use of this language in the classroom? } \\
\hline Very rarely & Rarely & Quite frequently & Not at all \\
\hline $28.3 \%(15)$ & $15.1 \%(8)$ & $43.4 \%(23)$ & $13.2 \%(7)$ \\
\hline \multicolumn{4}{|c|}{ Do you think that this lingua franca impinges on the good teaching quality of ESL? } \\
\hline \multicolumn{2}{|c|}{ Yes } & \multicolumn{2}{|c|}{ No } \\
\hline \multicolumn{2}{|c|}{$71.7 \%(38)$} & \multicolumn{2}{|c|}{$28.3 \%(15)$} \\
\hline \multicolumn{4}{|c|}{ Should Camfranglais be standardized to serve as a national language like Wolof in Senegal and Tswana in Botswana? } \\
\hline \multicolumn{2}{|c|}{ Yes, it should be standardized } & \multicolumn{2}{|c|}{ No, it shouldn't, it's a danger } \\
\hline \multicolumn{2}{|c|}{$30.1 \%$ (17) } & \multicolumn{2}{|c|}{$69.9 \%(37)$} \\
\hline
\end{tabular}

Table 5. Recap of the impact of French

\begin{tabular}{|c|c|c|c|}
\hline \multicolumn{4}{|c|}{ Do you use French to better teach English to your students? } \\
\hline Very rarely & Rarely & Quite frequently & Not at all \\
\hline $47.2 \%(25)$ & $24.5 \%(13)$ & $47.2 \%(25)$ & $7.5 \%(4)$ \\
\hline \multicolumn{4}{|c|}{ Are your students influenced by the French language in class, especially in speaking? } \\
\hline Very rarely & Rarely & Quite frequently & Not at all \\
\hline $1.9 \%(1)$ & $7.5 \%(4)$ & $83 \%(44)$ & $7.5 \%(4)$ \\
\hline \multicolumn{4}{|c|}{ What do you think accounts for this influence? } \\
\hline $\begin{array}{l}\text { This language is } \\
\text { pre-dominantly spoken } \\
\text { in Cameroon }\end{array}$ & $\begin{array}{c}\text { There is a significant number of } \\
\text { ESL learners from } \\
\text { French-speaking families }\end{array}$ & $\begin{array}{l}\text { Some ESL teachers also come from } \\
\text { French-speaking families }\end{array}$ & $\begin{array}{l}\text { It depends on the region } \\
\text { where the school is located }\end{array}$ \\
\hline $24.5 \%(13)$ & $35.8 \%(19)$ & $9.4 \%(5)$ & $30.2 \%(16)$ \\
\hline
\end{tabular}

When asked if their students used it in class and especially in speaking situations, $1.9 \%$ said they used it very rarely, $7.5 \%$ rarely, $83 \%$ quite frequently, and $7.5 \%$ said they did not use it at all. Finally, $24.5 \%$ of our informants said that this influence is due to the fact that the language is spoken in the majority in Cameroon, $35.8 \%$ said that this influence is due to the fact that there are a large number of ESL learners from Frenchspeaking families, $9.4 \%$ said that this influence is due to the fact that some ESL teachers also come from Frenchspeaking families and finally, $30.2 \%$ said that it depends on the region where the school is located. Once again, it is quite clear that in Cameroon, French has an impact and not just a little on the learning and teaching of ESL.

The purpose of adding an open-ended question in the questionnaire was to get the opinions of the participants about language planning in schools. Their answers were often very diverse. For most of the ESL teachers, in order to achieve a sound language system in secondary education in Cameroon, there is an urgent need to create a single national language so that the multitude of languages do not have to influence the teaching/learning of ESL. Moreover, regional languages (i.e., one language per region) should be determined so that the teachers as well as the students do not end up with a jumble of local languages in secondary education. Most of them think that CPE is not structured and that it is a big danger for the development of English, even if a small part of them thinks that this same CPE can become, if well structured, the unique national language. They do not seem to have much confidence in Camfranglais, accepting it as a colloquial language that may be a danger to English and French. Some also believe that if English is dying in Cameroon, it is certainly because of the poor quality of schoolbooks and the poor training of teachers that should be reviewed. The majority believe that a good command of the learner's first language (local language) is conducive to good ESL learning

\section{Conclusion and Recommendations}

The main objective of this study was to understand how ESL teaching is being organized in a multilingual context such as Cameroon's in order to determine the degree of impact that not only French and local languages have in this process but also the lingua francas (CPE and Camfranglais). Thus, we proceeded by administering questionnaires to a total of 53 ESL teachers spread across the Cameroonian national triangle. In doing so, the results generally revealed that English in Cameroon suffers from a certain marginalization due to the numerical importance of French, even though $62.3 \%$ of the informants think that the teaching of local languages in schools is an advantage for the learning of English, the majority (49\%) nevertheless think that a single national language is more appropriate in order to avoid 
linguistic disorder. The results also show that 83\% (for CPE) and $71.7 \%$ (for Camfranglais) of our informants think that these lingua francas have a negative impact on the learning/ teaching of ESL. However, 41.5\% (for CPE) and 69.9\% (for Camfranglais) of our informants think that these lingua francas should not be standardized. Regarding the impact of French or the degree to which it influences the learning of ESL, $1.9 \%$ said their students used it very rarely, $7.5 \%$ rarely, $83 \%$ quite frequently, and $7.5 \%$ said they did not use it at all. In view of all this, we deem it necessary to rethink the linguistic configuration in Cameroon, particularly in relation to education, so that the linguistic diversity that constitutes a jewel for Cameroon does not become a handicap. It is for this reason that we make the following recommendations:

1. The State should make sure that both official languages are treated equally

2. In order to avoid a multitude of languages in education which could be detrimental, a single national language or, in the worst-case regional languages (one language per region) should be adopted

3. The use of CPE and Camfranglais must be strictly regulated. They must be banned strictly in schools, and their use by teachers and students must be severely sanctioned. CPE can be used if standardized, thus giving birth to Cameroon English.

4. The training of ESL teachers must be rigid and effective, and their recruitment must be highly competitive as the learners look up to them.

5. The administrators of English schools in French-speaking areas must do everything possible to ensure that the French language, which already prevails because of its numerical power, does not overshadow the English language, which is the target.

We invite future researchers to pay particular attention to issues of multilingualism and bilingualism, given that Cameroon has an incredible linguistic diversity. Efforts must be made to ensure that the evolution of languages is in line with the fulfillment of its users.

\section{References}

Blasius, A.T., \& Lando, R. (2017). English in Cameroon: Issues of teacher language proficiency. International Journal of English Language, 4(1), 20-31. https://doi. org/10.5430/ijelt.v4n1p20

Blasius, A.T., \& Pius, W.A. (2014). Enhancing English language studies in Cameroon: The mother tongue perspective. California Linguistic Notes, 39(1), 23-47.

Chiatoh, B.A. (2012). Official bilingualism and the construction of a Cameroonian national identity. In G. Echu, \& A. A. Ebongué (Eds.), Fifty years of official language bilingualism in Cameroon (1961-2011): Situation, stakes and perspectives (pp. 65-85). L'Harmattan.

Chumbow, B.S. (1990). Language and language policy in Cameroon. In A. Kofele-Kale (Ed.), An African experiment in nation building: The bilingual Cameroon Republic since reunification (pp. 281-311). Westview Press.
Chumbow, B., S., \& Simo-Bobda, A. (1996). The Life cycle of post imperial English in Cameroon. In J. A. Fishman, A W. Conrad, \& A. R. Lopez (Eds.), Post-imperial English: Status of English after colonialism (pp. 22-43). Mouton de Gruyter.

Echu, G. (2003). Coping with multilingualism: Trends in evolution of language policy in Cameroon. PhiN, 25 , 31-46.

Ekembe, E.E. (2013). English as a foreign language at the University of Yaounde1: Attitudes and pedagogic practices. English Language Teaching, 6(3), 57-71.

Eloundou, V. (2021). Les langues nationales du Cameroun et le Camfranglais au coeur des representations glottophobes et glottophiles. Trans, 20, n.p. https:// www.inst.at/trans/20/les-langues-nationalesdu-cameroun-et-le-camfranglais-au-coeur-desrepresentations-glottophobes-et-glottophiles /

Fontem, N. (2012). Investigating modes of language acquisition and proficiency. Miraclaire Publishing.

Fontem, N.A., \& Oyetade, S.O. (2005). Declining Anglophone English language proficiency in Cameroon: What factors should be considered? In E. Chia (Ed.) Globalization and the African experience: Implications for language, literature and education (pp. 64-87). Anucam.

Gonondo. N., \& Djiraroe, M.C. (2016). The challenge of saving two languages in Cameroon higher education: The case of the public universities. Asian Journal of Social Sciences, Arts and Humanities, 4(3), 38-46. 